chowania. Przeprowadza studentów przez najważniejsze zagadnienia,ograniczając gąszcz literatury i materiałów źródłowych. Oznacza się dużą zwięzłością treści $i$ jest dostosowany do programu studiów pedagogicznych.

Justyna Gulczyńska

1 W. Błońska, Historia wychowania przewodnik dla studentów, Katowice 1977.
2 J. Krasuski, Historia wychowania dla studentów pedagogiki, Kielce 1974.

3 S. Możdżé, Kompendium bibliograficzne uczestnika seminarium historii wychowania, Warszawa 1977.

${ }^{4} \mathrm{Cz}$. Maziarz, E. Widota, Zagadnienia metodologii podrecznika akademickiego, Warszawa 1985, s. 94.

${ }^{3}$ E. Malewska, Czynniki dydaktyczne warunkujace proces ksztalcenia na I roku studiów, „Dydaktyka Szkoly Wyiszej", 1973, nr 1, s. 3.

\title{
Noty
}

\section{Marian Chachaj, Zagraniczna edukacja Radziwillów od początku XVI do polowy XVII wieku, Lublin 1995, ss. 171}

Praca M. Chachaja omawia zagraniczne nauki kilku pokoleń rodu Radziwiłłów. Ród ten należał do najbardziej wykształconych na Litwie.

Autor przedstawia najpierw pierwsze wojaże edukacyjne odbyte przez synów Mikołaja Radziwilła Czarnego przypadające na pierwsza połowe wieku XVI - Jana, Mikołaja i Stanisława. Linia birżańska rodu aż do schyłku XVI wieku nie wysyłała synów na nauki za granice, uczynił to dopiero Krzysztof Piorun, który docenial znaczenie nauki i staral się aby jego synowie byli ludżmi wykształconymi i doszli w państwie, gdzie coraz większe wpływy mieli katolicy, do znaczących stanowisk. Nasilająca się moda na wyjazdy zagraniczne młodzieży zapewne również miała w tym swój udział. Dwaj synowie Pioruna - Janusz i Krzysztof odbyli długie podróże zagraniczne, odwiedzając wiele ośrodków uniwersyteckich. Kolejne pokolenie odbywające zagraniczne nauki to przedstawiciele galęzi katolickiej - synowie Mikołaja Krzysztofa Sierotki - Jan, Albrycht, Krzysztof, Zygmunt i Aleksander. I wreszcie Janusz i Bogusław Radziwiłłowie - przedstawiciele kalwińskiej linii. Omówieniu zagranicznych podróży tych wszystkich przedstawicieli rodu Radziwiłłów poświęcil Autor pierwsze cztery rozdziały pracy. Piąty natomiast stanowi próbe podsumowania, wyciągnięcia wniosków, ukazania konsekwencji i rezultatów za- granicznych nauk Radziwiłłów. Uzupełnieniem jest wykaz źródeł i literatury, indeks nazwisk oraz tablica studiów i podróży Radziwiłłów.

Szlachecka i magnacka edukacja w omawianym okresie była kilkuetapowa. Po naukach w kraju - najczęściej w przypadku młodzieńców pochodzenia magnackiego - prywatnych lub odbywanych w szkołach krajowych - wysyłano synów za granice. Dokąd, to zależato ad wielu czynników - tradycji rodzinnej, mody, wyznania $\mathrm{i}$ in. Za granica albo podejmowano naukę $w$ jakiejś szkole, albo brano lekcje prywatne, a ponadto - był to ważny element peregrynacji - zwiedzano, poznawano, oglądano... Tak w ogólnych zarysach wyglądała również nauka Radziwiłłów. Autor stara się wykazać, że na pewne odmienności w zasadniczym modelu edukacji wpływało wyznanie. I rzeczywiście wyznanie warunkowało wybór trasy, wybór ośrodków studiów, ale generalnie profil edukacji pozostawał bardzo zbliżony niezależnie od wyznania Ojcowie starannie dobierali trasę podróży, tak aby ustrzec młodzieńców przed niepożądanymi wpływami religijnymi, szczególnie podkreślali to innowiercy, pamiętając zapewne słynna konwersje Sierotki.

Praca oparta jest na materiałach żródłowych rękopiśmiennych polskich i obcych, żródlach drukowanych oraz literaturze naukowej.

Dorota Żolqdż-Strzelczyk 